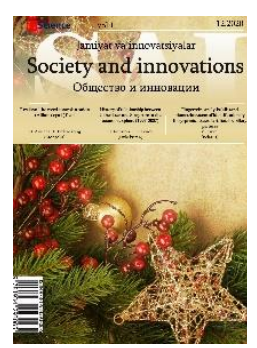

\title{
Socio-legal significance of interaction of bodies ofpre-trial proceedingsin disclosure and investigation of crimes
}

\section{Dilrabo KARIMOVA ${ }^{1}$}

Ministry of internal Affairs of the Republic of Uzbekistan

\section{ARTICLE INFO}

Article history:

Received September 2020

Received in revised form

15 October 2020

Accepted 15 November 2020

Available online

31 December 2020

\section{Keywords:}

Interaction

Criminal procedure

Investigator

Operational-search activity

Bodies ofpre-trial

proceedings.

\begin{abstract}
The author of the article reveals the socio-legal conditionality of implementation of interaction between the bodies of pre-trial proceedings in the activity of disclosing and investigating committed crimes. The urgency of studying the essence and meaning of this interaction is substantiated. The concept of interaction is considered from the point of view of different branches of knowledge. The opinions and views of domestic and foreign scientists regarding the concept and meaning of interaction, both a social phenomenon and a legal category, implying conscious, coordinated, joint and purposeful actions of bodies of pre-trial proceedings are analyzed. The author's definition of the concept of interaction between the bodies of pre-trial proceedings is given. The author states the unsatisfactory state of interaction of the bodies of pre-trial proceedings, in particular, interrogators, investigators with the bodies carrying out pre-investigation checks and operationalsearch activity based on the sociological studies carried out on organization of activities for the disclosure, investigation of crimes and the search for persons hiding from the court and investigation. The author sees the solution to these problems in strengthening the effective measures of law enforcement agencies in combating crime, active and effective use of possibilities of criminal procedural and operational search activities.
\end{abstract}

2181-1415/C) 2020 in Science LLC.

This is an open access article under the Attribution 4.0 International (CC BY 4.0) license (https://creativecommons.org/licenses/by/4.0/deed.ru)

\footnotetext{
${ }^{1}$ Doctor of Philisophy (PhD)in Law, associate professor,Academy of the Ministry of internal Affairs of the Republic of Uzbekistan

E-mail: doctor.кarimova.d@mail.ru
} 


\section{Жиноятларни очиш ва тергов қилишда судга қадар иш юритиш органларининг ўзаро хамкорлигининиг ижтимоий-хуқуқий ахамияти}

\author{
Калит сўзлар: \\ Хамкорлик \\ Жиноят процесси \\ Терговчи \\ Тезкор-қидирув фаолияти \\ Судга қадар иш юритиш \\ органлари.
}

\section{АННОТАЦИЯ}

Мазкур мақолада муаллиф томонидан жиноятларни очиш ва тергов қилиш фаолимятида судга қадар иш юритиш органлари ўртасидаги ўзаро хамкорликнинг ижтимоий-хуқуқий шартлилиги ёритилган. Ушбу хамкорликнинг мохияти хамда ақамиятини ўрганиш долзарблилиги асослантирилган. Хамкорлик тушунчаси билимларнинг турли сохалари нуқтаи назаридан кўриб чиқилган. Юртимиз ва чет эл олимларининг хамкорлик тушунчаси ва ахамиятига оид фикрлари хамда қарашлари ижтимоий ходиса, шунингдек юридик тоифа сифатида тахлил этилиб, судга қадар иш юритиш органларининг онгли, изчил, мақсадга йўналтирилган харакатлари назарда тутилиши белгиланган. Судга қадар иш юритиш органларининг ўзаро хамкорлиги иборасининг муаллифлик тушунчаси берилган. Муалифф жиноятларни очиш, тергов қилиш, суддан ва терговдан яширинган шахсларни қидириб топиш бўйича тадбирларни ташкил этиш юзасидан ўтказилган социологик тадқиқотлар асосида судгача иш юритиш органларининг, хусусан, терговчининг терговга қадар текширув ва тезкор-қидирув фаолиятни амалга оширувчи органлар билан ўзаро хамкорлиги холати қоникарсиз эканлиги аниқлаган.Ушбу муаммоларнинг ечимини муаллиф хуқуқни мухофаза қилиш идораларининг жиноятчиликка қарши курашиш сохасидаги самарали чораларини кучайтиришда, жиноят процессуал ва тезкор-қидирув фаолияти имкониятларидан фаол ва самарали фойдаланишда кўради.

\section{Социально-правовое значение взаимодействия органов досудебного производствав раскрытии и расследовании преступлений}

\footnotetext{
Ключевые слова:

Взаимодействие

Уголовный процесс

Следователь

Оперативно-розыскная

деятельность

Органы досудебного

производства.
}

\begin{abstract}
АННОТАЦИЯ
В данной статье автором раскрывается социальноправовая обусловленность осуществления взаимодействия между органами досудебного производства в деятельности по раскрытию и расследованию совершенных преступлений. Обосновывается актуальность изучения сущности и значения данного взаимодействия. Понятие взаимодействие рассматривается с точки зрения разных отраслей знаний. Анализируются мнения и взгляды отечественных и зарубежных ученых относительно
\end{abstract}




\begin{abstract}
понятия и значения взаимодействия, как социального явления, так и юридической категории, подразумевающие сознательные, согласованные, совместные и целенаправленные действия органов досудебного производства. Приводится авторская дефиниция понятия взаимодействия органов досудебного производства. На основе проведенных социологических исследований по организации деятельности по раскрытию, расследованию преступлений и розыску лиц, скрывающихся от суда и следствия, автором констатируется неудовлетворительное состояние взаимодействия органов досудебного производства, в частности, дознавателей, следователей с органами, осуществляющими доследственную проверку и оперативно-розыскную деятельность. Решение данных проблем автор видит в усилении действенных мер правоохранительных органов в сфере борьбы с преступностью, активного и эффективного использования возможностей уголовно-процессуальной и оперативнорозыскной деятельности.
\end{abstract}

\title{
INTRODUCTION
}

At present, crime, developing in parallel with society, complicates the effectiveness of ensuring the safety of citizens, protecting their rights and freedoms from criminal encroachments. The activities of criminals are increasingly characterized by a high degree of professionalism. The dramatically increased mobility, modern technical equipment has significantly increased the possibility of implementing a criminal plan.

Empirical observations of the activities on organizing the disclosure of crimes, the search for persons hiding from the investigation and the court, require a separate scientific analysis of the issues of interaction between the bodies of pre-trial proceedings, in particular, bodies carrying out investigative and operational-search activities.

Issues of improving the international and national mechanisms in the world, aimed at ensuring mutual and departmental interaction of law enforcement agencies in prevention, disclosure and investigation of crimes presuppose deep systemic and research work in this direction. At the same time, generalization of the achievements in finding solutions to problems related to procedural theory and judicial-investigative practice of interaction is important; understanding the essence and meaning, precise definition of the rights and obligations of subjects of interaction, development of its mechanism, ensuring effective interaction of pre-trial proceedings in the rapid, full disclosure and objective, qualitative investigation of the crimes committed.

The President of Uzbekistan, critically assessing the activities of the internal affairs bodies, points to serious shortcomings in the research activity, especially to the currently observed insufficient degree of organization of interaction in the lower divisions of law enforcement agencies [1].

In the Action Strategy for five priority areas of development of the Republic of Uzbekistan in 2017-2021 to ensure the rule of law and further liberalization of the judicial and legal system, it is determined "to increase the efficiency of coordinating activities in the fight against crime and prevention of offenses" [2]. 
The above-mentioned provides for the implementation in this direction of such tasks as the radical improvement of the activities of bodies of pretrial proceedings to increase the efficiency of their interaction, the fight against crime and protection of public order, consolidate in their activities the guarantees of reliable protection of the rights and freedoms of citizens, the introduction of the latest innovative management technologies, as well as the organization at the highest level of interaction with the population.

\section{MATERIALS AND METHODS}

Statistics show that in the fight against crime in recent years, carried out in cooperation with departmental services of law enforcement agencies, there is a decrease in the commission of crimes, namely: for 2016 by $0.56 \%$, for 2017 by $0.88 \%$, for 2018 by $1.58 \%$, for 2019 by $1.63 \%$ [3]. At the same time, there is an almost 2.5 -fold increase in the number of cases of hooliganism (153 in 2019, 385 in 2020), twice - the number of crimes related to fraud (3124 in 2019, 2712 in 2020), bribery (280 in 2019, 557 in 2020). The number of cases of robbery also increased (from 38 to 74) and theft (from 1293 to 2097) [4]. An analysis of the organization of activities for the disclosure, investigation of crimes and the search for persons hiding from the court and investigation indicates the unsatisfactory state of interaction of the bodies of pre-trial proceedings, in particular, interrogators, investigators with the bodies carrying out pre-investigation checks and operational-search activities.

Often, precisely due to the weak organization of interaction of subjects of disclosure and investigation, crimes remain unsolved. This situation requires law enforcement agencies to take effective measures in the fight against crime, actively and effectively use the possibilities of criminal procedural and operational-search activities.

This is due to the fact that one, even a very qualified interrogator, investigator or even a group of investigators, as well as other bodies of pre-trial proceedings, without systemic interaction with each other, are unable to cope with the disclosure and investigation of crimes. The interaction is primarily due to the fact that, for example, an interrogator, an investigator and the bodies carrying out pre-investigation checks and operational-search activities, have specific, only inherent procedural actions, means, methods and ways of participating in the disclosure and investigation of crimes.

For, as the American politician Daniel Webster justly noted, people together can accomplish what they cannot do alone; the unity of minds and hands, the concentration of their forces can become almost omnipotent" [5, p.192.].

Thus, the study of the essence and significance of the considered interaction, in our opinion, is very relevant.

It is well known that "interaction" has a universal character, that is, it is applicable to one degree or another to any social phenomenon, since despite its apparent simplicity, "interaction" has ambiguity in the definitions of the concept, the specificity of the essence, the multidimensionality and diversity of internal and external connections and relationship between interacting subjects. Therefore, revealing the essence and meaning of this concept, it is necessary to take into account its semantic meaning.

The concept of "interaction" from the point of view of different branches of knowledge has a different interpretation. Let us compare only with a few - related to the subject of our issue. 
So, in philosophical science, interaction acts as a special category, reflecting the process of the influence of objects on each other, their mutual conditioning. Interaction, as a universal form of movement of development, determines the existence and structural organization of any material system [6, p.199].

In sociology, interaction is considered as a form of social communication of at least two persons, or communities, in which their influence on each other is systematically carried out [7, p.8].

In the science of social management, interaction acts as one of the elements of organization of management, as an independent function of directed influence, carried out to achieve a specific goal [8, p.68, p.76].

If to pay attention to the etymological meaning of the terms, then it should be noted that the word "interaction" is interpreted as a mutual connection; consistency of actions $[9$, p.36]. In turn, S.I. Ojegov, under the interaction with the exact meaning of the word, considered mutual support [10, p. 83].

In this case, it is interesting to refer to the content of the term "interaction" in English, as the main international language. So, the concept of interaction in English is covered by such words as: interaction; co-operation; reciprocity; intercommunion; interplay; teamplay; engagement; coordination; cohesion; interoperability; conjunction; mutual effect; coordinate action; correlation; intercourse; cross impact; reciprocal influence [11].

A. Reber's big explanatory psychological dictionary describes interaction as mutual impact or influence. In social interaction, the behavior of one acts as a stimulus for the behavior of another, and vice versa. In static interaction, the effects of two (or more) variables are interdependent [12, p.130].

In one of the most authoritative legal encyclopedic dictionaries, Black's Law Dictionary, interaction is defined as "cooperation", an act of cooperation or joint action with someone; bringing people together for a common benefit; and others [13, p.334].

From the above, it can be seen that the concept of interaction (according to foreign experience) means social ties of a special nature, first of all, coordination of actions, cooperation, influence on each other, mutual connection, mutual support, uniting people for the sake of common benefit. Interaction can be considered both as a process (for example, influence on each other) and as a result (for example, coordination of actions, interconnection, cooperation).

The given concepts are similar in that they are based on the fundamental philosophical essence. Returning to the concept of interaction in philosophy, let us pay attention to the fact that interaction presupposes the influence of objects on each other, their mutual conditionality, and that this form of development determines the existence and structural organization of any material system.

This is important for us, since at present the bodies of pre-trial proceedings in all their inherent competences are the bodies of independent systems, although they have a common goal, which is a significant prerequisite for considering their relationship in a single system. So, reasoning on almost all issues, including the concept of "interaction", should, if possible, have a systemic approach to their analysis.

Since, as noted by Sh.O. Mamadaliyev: "The systemic approach, as a direction of philosophy and methodology of scientific knowledge, considering an object as an integral 
complex of interrelated elements, orients it towards identifying its regular connections" $[14$, p.39].

Taking into account that the systemic approach is based on the principles of integrity, structuring, plurality, consistency, hierarchy, then all these principles are relevant in the problem we are investigating.

Based on this approach, it should be noted that in any socially operating systems (the systems we are considering are no exception), interaction does not exist spontaneously, it is organized and, if necessary, is normatively regulated and develops. Therefore, when considering this issue, we often use the expression "organization of interaction". This makes it possible to determine the interaction of the bodies of pre-trial proceedings as a single organizational process.

From the above definitions it follows that "interaction" presupposes the presence of certain relations, mutual rights and obligations in the activities of participants in criminal procedural legal relations. Moreover, such activities have the nature of joint actions, involving mutual support of these participants.

The procedural definition of interaction as an institution of criminal procedure is of interest. In the scientific and legal aspect, the term "interaction" is understood as the interconnected activity of specific subjects and units carrying out pre-trial proceedings. Various definitions of this interaction are given in the legal literature.

For example, according to L.N. Kalinkovich, interaction, as a legal category, denotes the activities of various state bodies that have an independent legal status coordinated in terms of goals, place, time and tactics [15, p.73].

So, A.A. Mukhiddinov considers interaction as an activity based on the law and normative-legal and departmental acts, carried out in order to prevent, disclose and investigate crimes, as well as search for criminals and identify the person who committed the crime [16, p. 151].

Sh.F. Fayziyev, on the other hand, considers the interaction we are examining as the relationship of an interrogator, an investigator with the chief of bodies carrying out preinvestigation checks or operational-search activities, based on the law and not subordinate to each other in the administrative aspect of the agreed actions of these subjects [17, $\mathrm{p}$. 160].

F.M. Kobzarev regarding procedural interaction in the sphere of criminal proceedings argues that interaction as a specific form of these connections and relations acts as the main systemic category, through which the essence of the activity side of relations of participants in criminal proceedings is most fully and comprehensively disclosed [18, p. 4-5].

According to N.P. Yablokov and V.V. Krylov, interaction is a law-based and agreed on all principal conditions activity of these persons and bodies, aimed at crime detection and solving all other problems of their investigation and prevention [19, p. 363].

N.A. Amenitskaya, considering the relationship between the operational-search and criminal-procedural activities, draws attention to the fact that "the mutual connection of the operational-search and criminal-procedural activities is manifested in the unity of purpose and the commonality of their tasks" [20, p. 10].

A. Kozusev also, in our opinion, justly notes that "The interaction of the operationalsearch bodies and investigators does not mean service subordination, the merger of 
procedural and operational-search activities. Each of them continues to remain an independent body, acting in strict accordance with its competence" [21, p. 10].

The judgment of F.M. Mukhiddinov, who, by interaction, means a variety of procedural and functional relations that make up the overall system of criminal procedure [22, p. 20].

Indeed, if the activities of the subjects of disclosure and investigation in interaction are considered as one of the forms of criminal procedure, consisting of separate, specific parts, then all these parts together form a general system of criminal procedure.

Taken together, all of the above concepts reflect the conscious, coordinated, joint purposeful actions of the bodies of pre-trial proceedings. So, the procedural interaction we are considering is the joint, coordinated activity of the pre-trial proceedings along the entire length of the process of disclosing and investigating crimes, starting from the moment of accepting statements, reports of a committed crime to sending the criminal case to court (author's definition).

\section{RESULTS AND ITSDISCUSSION}

The socio-legal significance of interaction of the bodies of pre-trial proceedings lies in the fact that in the fight against crime it provides:

- coordination of forces and means of bodies that, in accordance with procedural legislation, have the capabilities to carry out a particular activity;

- concentration of forces and means to fight the most serious crimes, including interregional and international crimes;

- timely detection of signs of crimes, their quick disclosure, initiation, investigation of criminal cases, as well as ensuring the protection of individual rights and freedoms from unlawful encroachments.

In our opinion, U.T. Tajikhanov and S.T. Akhmedov rightlynoted the essence of interaction that "the creative application of the provisions establishing the rules for the division of labor in the investigation of crimes allows, with a minimum expenditure of effort and resources, to optimally organize the labor of the participants in the investigation" [23, p. 20].

\section{CONCLUSIONS}

Based on the above-mentioned, it can be stated that the interaction of pre-trial proceedings is necessary for successful solution of tasks of quick, complete disclosure and comprehensive, objective investigation of crimes in order to ensure human rights and freedoms, through the comprehensive use of both criminal procedural actions and operational-search measures.

Taking into account the above opinions, the following definition can be given to the interaction of pre-trial bodies: the interaction of pre-trial bodies is based on the law and by-laws, joint, coordinated in purpose, place, time, activities of administratively independent bodies, which are expressed in the most effective combination of criminal procedural and operational-search functions, aimed at the timely and complete disclosure of crimes, bringing to criminal responsibility the person who committed the crime, searching for the accused, compensation for damage caused by the crime, as well as preventing and suppressing impending crimes, which involves the independent execution of each of its participants in their planned actions. 
The definition we propose does not claim to be exhaustive and is an attempt to find the correct ratio of the most characteristic signs of interaction between the bodies of pretrial proceedings.

\section{REFERENCES:}

1. Mirziyoyev Sh. M.Decisively continuing our path of national development, we will raise it to a new level. - T., 2017.- p. 317.

2. Decree of the President of the Republic of Uzbekistan of February 7, 2017 DP4947 "On the Action Strategy for further development of the Republic of Uzbekistan". Access mode: https://lex.uz/docs/3107042// www.lex.uz.

3. Statistical data of the IC MIA 2016-2019.

4. Access mode: https://www.gazeta.uz/ru/2020/06/30/crime/(date of appeal November 3, 2020).

5. Kurilla I.I. "Entering the circle of Great Powers...": Daniel Webster and U.S. Foreign Policy in the mid-19th century. Volgograd, 1997.- p. 192.

6. Big encyclopedia dictionary. - M., 2000. p. 199.

7. Big sociological encyclopedia. - M., 1991. - T.5. - p.8.

8. See: S.T. Akhmedova. "Basic principles and forms of implementation of legality in the administrative activities of the internal affairs bodies" // Huquq-Pravo-Law. - 1998. No.2. - p.68.; A.G.Markushin.Fundamentals of management in the internal affairs bodies. N. Novgorod, 2006. - p.76;

9. See: V.V.Lopatin, L.E. Lopatina. Russian Explanatory Dictionary - M., 1998. - p.36.

10. S.I. Ojegov. Dictionary of the Russian language. - M., 1990.- p. 83.

11. See: K.M. Levitan and others. English-Russian and Russian-English law dictionary.- M., 2015. - p.512. All possible translations of this concept can be conditionally grouped into groups that describe: the static state of a system consisting of subjects or objects; the possibility of functioning (movement) of such a system; the process of movement of such a system, that is, the process of interaction; the moment of movement of such a system, that is, the state of any system in a certain shortest time period of its movement; information exchange in the system; interconnection of elements within the system; counter reflection of objects on each other.

12. A. Reber. Big explanatory psychological dictionary. - M.: Veche, 2003. p.130.

13. Cooperation. Action of co-operating or acting jointly with another or other. Association of persons for common benefit // Black's Law Dictionary. St. Paul, Minn.: West Publishing, 1990. - P. 334.

14. Sh.O. Mamadaliyev.Methodology of conducting a research: Study guide. - T., 2015.- p. 39.

15. Kalinkovich L.N. Interaction of law enforcement agencies in the detection and investigation of crimes - the organizational basis for success // Law of Belarus. - 2002. No.13. - P.73.

16.

A.A.Mukhiddinov.Theproceduralpositionoftheinvestigatorinthecriminalprocess. Diss... Candidate of legalsciences. - T., 2009. - P. 151.

17. Sh.F. Fayziyev.Interaction of investigative and inquiry bodies: Monograph. - T., 2011.- p.160. 
18. F.M. Kobzarev. Problems of theory and practice of procedural and organizational relations between the prosecutor's office and the court in criminal proceedings. Abstract... Doctoroflegalsciences. - M., 2006. - p. 4-5.

19. Forensic science: textbook // Responsible editor. N.P.Yablokov.-M., 1999. p.363.

20. N.A. Amenitskaya.Interaction of the investigator and bodies carrying out operational-search activities in the disclosure and investigation of crimes in the internal affairs bodies: Abstract. dis.... Candidateoflegalsciences. - NizhnyNovgorod, 2006.- p.10.

21. A.Kozusev.Supervision over the execution of laws in operational-search activity // Legality. - 1997. - No.2.- p.20.

22. F.M. Mukhiddinov.Criminal procedure form: problems, theories and methodologies: Abstract. dis. ... Doctor of legal sciences. - T., 2005.- p.20.

23. U.Tajikhanov, S.T. Akhmedova. Fundamentals of organization of management in internal affairs 